\title{
Diversity of fluid geochemistry affected by processes during fluid upwelling in active hydrothermal fields in the Izena Hole, the middle Okinawa Trough back-arc basin
}

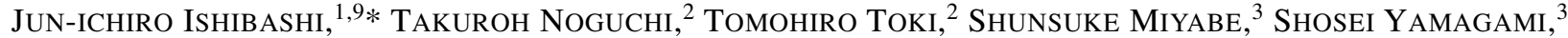 \\ YUJI ONISHI, ${ }^{3}$ TOSHIRO YAMANAKA,${ }^{3}$ YUKa YOKOYAMA, ${ }^{4}$ ERIKO OMORI,${ }^{4}$ YOSHIO TAKAHASHI,${ }^{4}$ \\ Kenta Hatada, ${ }^{5}$ Yuzuru Nakaguchi, ${ }^{5}$ Motoko Yoshizaki, ${ }^{6,7}$ Uta Konno, ${ }^{8,9}$ TaKazo Shibuya, ${ }^{7,9}$ \\ KEN TAKAI, ${ }^{7,8,9}$ FUMIO INAGAKI ${ }^{10}$ and SHINSUKE KAWAGUCCI ${ }^{7,8,9}$ \\ ${ }^{1}$ Department of Earth and Planetary Sciences, Faculty of Science, Kyushu University, Higashi-ku, Fukuoka 812-8581, Japan \\ ${ }^{2}$ Faculty of Science, University of the Ryukyus, Nishihara, Okinawa 903-0213, Japan \\ ${ }^{3}$ Graduate School of Natural Science and Technology, Okayama University, Okayama, Okayama 700-8530, Japan \\ ${ }^{4}$ Graduate School of Science, Hiroshima University, Higashihiroshima, Hiroshima 739-8526, Japan \\ ${ }^{5}$ School of Science and Engineering, Kinki University, Higashiosaka, Osaka 577-8502, Japan \\ ${ }^{6}$ Graduate School of Science and Engineering, Tokyo Institute for Technology, Meguro-ku, Tokyo 152-8551, Japan \\ ${ }^{7}$ Precambrian Ecosystem Laboratory (PEL), Japan Agency for Marine-Earth Science and Technology (JAMSTEC), \\ Yokosuka, Kanagawa 237-0061, Japan \\ ${ }^{8}$ Institute of Biogeosciences (Biogeos), Japan Agency for Marine-Earth Science and Technology (JAMSTEC), \\ Yokosuka, Kanagawa 237-0061, Japan \\ ${ }^{9}$ Submarine Resources Research Project (SRRP), Japan Agency for Marine-Earth Science and Technology (JAMSTEC), \\ Yokosuka, Kanagawa 237-0061, Japan \\ ${ }^{10}$ Kochi Institute for Core Sample Research, Japan Agency for Marine-Earth Science and Technology (JAMSTEC), \\ Nangoku, Kochi 783-8502, Japan
}

(Received September 1, 2013; Accepted April 6, 2014)

\begin{abstract}
Two active hydrothermal fields, Jade and Hakurei fields have been discovered within the Izena Hole, a rectangular 6 $\mathrm{km} \times 3 \mathrm{~km}$ shape depression located in the middle Okinawa Trough back arc basin. In both fields, intense hydrothermal activity is represented by venting of high-temperature fluid $\left(>300^{\circ} \mathrm{C}\right)$ and occurrence of sulfide/sulfate ore deposits. We collected hydrothermal fluids during dive expeditions of ROV Hyper Dolphin conducted in 2003, 2010 and 2011, in order to analyze both elemental and gas species. The geochemistry of high temperature hydrothermal fluids collected from the Jade and Hakurei fields is very similar to each other with exceptions in minor gas composition. Little temporal variation was observed in geochemistry of the high-temperature hydrothermal fluid of the Jade field over two decades, since a previous study carried out in 1989. These results suggest that these fluids are derived from a common fluid reservoir where fluid chemistry is basically controlled by fluid-mineral equilibria and gas species are dominantly contributed from the same magma. Venting of low temperature fluid (about $104^{\circ} \mathrm{C}$ ) was discovered in the distal part of the Jade field, which was named as the Biwako vent. Chemical composition of the Biwako vent fluid was distinctive from that of the high temperature fluid in the proximal part of the Jade field, and could not be explained by simple dilution or cooling. This intra-field chemical diversity could be caused by phase separation and segregation during fluid upwelling, based on relationships in concentrations of $\mathrm{Cl}$ and major cations. On the other hand, the chemical diversity recognized in minor gas composition between the Jade and Hakurei fields is in accordance with results from previous plume survey. Difference in concentrations of minor gases such as $\mathrm{H}_{2}$ is attributed to contribution from thermal degradation of organic matter in the sediment, during fluid upwelling.
\end{abstract}

Keywords: hydrothermal fluid circulation system, phase separation, fluid-sediment interactions, magmatic volatiles, thermal decomposition of organic matter, Okinawa Through

*Corresponding author (e-mail: ishibashi.junichiro.779@m.kyushuu.ac.jp)

Copyright @ 2014 by The Geochemical Society of Japan.

\section{INTRODUCTION}

Since discovery of high temperature fluid venting from the seafloor more than 35 years ago, numerous studies have established the key processes controlling fluid chemistry during fluid circulation beneath the seafloor (e.g., 

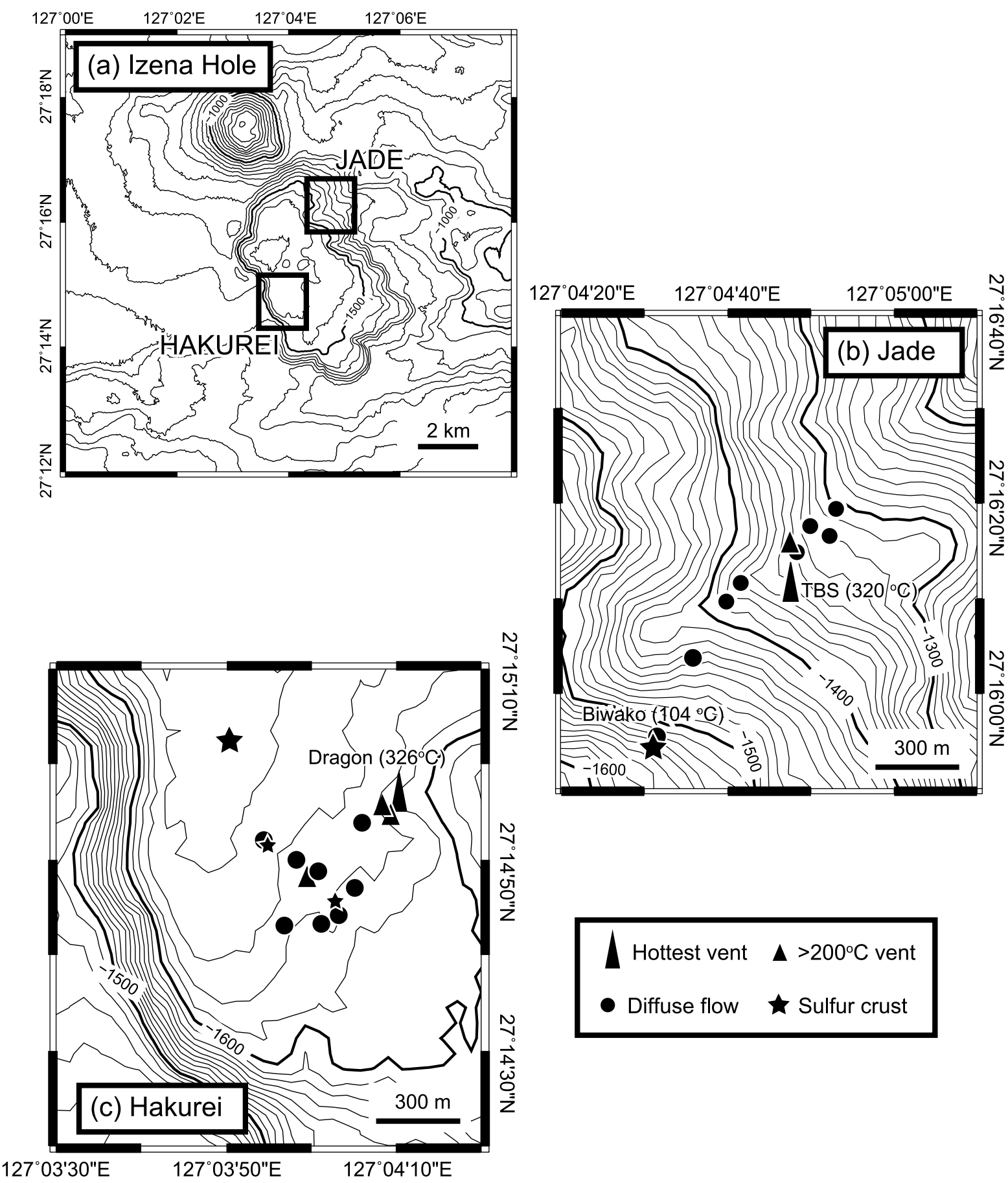

Fig. 1. Topographic maps of the Izena Hole (a), the Jade hydrothermal field (b), and the Hakurei hydrothermal field (c).

Butterfield et al., 2003; German and Von Damm, 2004; Tivey, 2007). Cold seawater penetrating into the subseafloor is altered significantly by chemical and microbial processes within crust and/or sediment at the fluid recharge stage (e.g., Tivey, 2007; Kawagucci et al., 2011). High temperature fluid-mineral interactions at the reaction zone primarily constrain chemical characteristics of venting fluid (e.g., Seyfried, 1987). In addition, processes during fluid upwelling at the discharge stage also impact on fluid chemistry (e.g., Proskurowski et al., 2008).

Fluid chemistry of hydrothermal systems in the Okinawa Trough back-arc basin has been characterized by enrichment in $\mathrm{CO}_{2}, \mathrm{CH}_{4}, \mathrm{NH}_{4}{ }^{+}$, and $\mathrm{K}$ compared with those in typical sediment-free Mid Ocean Ridge (MOR) 
hydrothermal fluids (Sakai et al., 1990a; Gamo et al., 1991; Ishibashi et al., 1995; Konno et al., 2006; Suzuki et al., 2008; Kawagucci et al., 2011, 2013). The difference in fluid chemistry has been related to the tectonic setting of rifting in the continental margin and fluid interactions with thick terrigenous/volcanic sediments on the seafloor (Gamo et al., 2006). Moreover, a recent study pointed out compositional and/or isotopic variations among hydrothermal fluids collected from the Okinawa Trough, especially for species associated with fluidsediment interactions such as $\mathrm{H}_{2}, \mathrm{CH}_{4}$, and $\mathrm{Sr}$ (Kawagucci et al., 2013). As demonstrated in these previous studies, chemical processes across the entire sub-seafloor fluid circulation system control the fluid chemistry of hydrothermal fields in sediment-rich environments.

The Izena Hole is a rectangular shape depression with a size of about $6 \mathrm{~km} \times 3 \mathrm{~km}$ (Fig. 1), which is located in the middle Okinawa Trough. Two active hydrothermal fields, Jade field and Hakurei field have been discovered in the Izena Hole. In both fields, hydrothermal activities were associated with venting of high-temperature $\left(>300^{\circ} \mathrm{C}\right.$ ) fluid and abundant occurrence of sulfide/sulfate ore deposits. The Jade field is located at an inside slope of the northeastern wall of the Izena Hole (Fig. 1). Since its discovery in 1988 (Halbach et al., 1989, 1993), the Jade field has been abundantly investigated (Nakamura et al., 1989; Sakai et al., 1990a, b; Ishibashi et al., 1995; Kinoshita and Yamano, 1997; Marumo and Hattori, 1999). The Hakurei field is located at the southern part of the bottom seafloor of the Izena Hole. In this field, scientific research with manned submersible or Remotely Operated Vehicle (ROV) was not yet conducted until this study. Since 2008, the Hakurei field has been explored intensively by JOGMEC (Japan Oil, Gas and Metals National Corporation) under a framework of the ocean energy and mineral resources development program. Despite the vicinity of these two sites within $3 \mathrm{~km}$, a previous water column survey above the Izena Hole revealed more than one-order higher $\mathrm{H}_{2} / \mathrm{CH}_{4}$ ratio in the hydrothermal plume above the Hakurei field than that above the Jade field (Kawagucci et al., 2010a). On the other hand, seismological investigations during the R/V Kaiyo KY02-11 cruise in 2002 reported notable geological differences between these two fields. The Hakurei field is covered with a thick sediment layer (more than 150 meters), whereas a few-meters thin sediment layer is recognized at the Jade field (Y. Nakamura, personal communication). The observed different chemical characteristics of the hydrothermal plumes between two fields could be related to difference in local sedimentary condition of the seafloor, because both $\mathrm{H}_{2}$ and $\mathrm{CH}_{4}$ are chemical species contributed from fluid-sediment interactions. A geochemical study of venting fluids was expected to reveal these processes.
We will report here a result of our investigation with ROV Hyper Dolphin that collected hydrothermal fluids from the Jade and Hakurei fields in the Izena Hole in 2003, 2010, and 2011 during the cruises of R/V Natsushima NT03-09, NT10-17, and NT11-15. We confirmed little temporal variation of geochemistry of high temperature hydrothermal fluid of the Jade field over two decades since the previous study (Sakai et al., 1990a). We discovered venting of low temperature vent fluid in the distal part of the Jade field, which showed distinctive chemical characteristics from the high temperature fluid. We revealed geochemistry of high temperature hydrothermal fluid collected from the Hakurei field were very close to that of the Jade field, with a few exceptions. One of the exceptions was difference in minor gas composition that was expected by the previous plume survey. We will discuss factors to cause these diversities in fluid chemistry collected from the adjacent active hydrothermal fields, and demonstrate importance of chemical modification by fluid-sediment interactions during fluid upwelling.

\section{GEOLOGICAL BACKGROUND AND OBSERVATIONS}

Formation of the Izena Hole is considered to be related to rifting activity of the middle Okinawa Trough based on its peculiar topography. For example, steep gradient and horseshoe depressions were notable especially on the southeastern wall, which could be attributed to results of recent fault activities (Kato et al., 1989; Kato, 1990). On the other hand, it is difficult to recognize whether magmatic activity in this area should be ascribed to a volcanic front or a back-arc rifting. The Izena Hole is situated along plausible southwestern continuation of a chain of Quaternary volcanoes of the Ryukyu arc (Shinjo et al., 1999). Its location can be also considered as the eastern end of the Aguni rift graben segment (Halbach et al., 1993). Abundant tuff breccia and woody pumice of dacitic composition were observed as exposed on the hole slopes. A center-cone like a small knoll consisted of dacite lava was recognized at the center of the hole during past dive surveys (Kato et al., 1989; Kato, 1990). These observations suggest recent magmatic activity, although detailed petrology of volcanic rocks in the Izena Hole have not been studied.

Present hydrothermal activity in the Izena Hole was firstly discovered in 1988 by towed video camera surveys and dredges of hydrothermal ore deposits during SO56 cruise lead by a German scientific team (Halbach et al., 1989). This site was named as "Jade" in commemoration of Japan-Deutsche collaboration during this cruise. Geochemical studies on the hydrothermal activity were conducted during following dive missions in 1988 and 1989 (Sakai et al., 1990a, b; Ishibashi et al., 1995). The Jade field is located on the northeastern slope of the Izena 
Hole at water depth of 1300-1550 m. Hydrothermal activity was recognized in an area of $500 \mathrm{~m} \times 300 \mathrm{~m}$. Venting of the fluid having recorded the highest fluid temperature of $320^{\circ} \mathrm{C}$ at "TBS" chimney was located at 1350 $\mathrm{m}$ in depth, where "black smoker" had been reported in 1989 (Sakai et al., 1990a). Chimneys associated with moderate to high temperature fluid venting were concentrated in the neighbor of the TBS chimney, which is regarded as the proximal part of the Jade field (Fig. 1). Based on visible observations during 2003 and 2011 surveys, fluid venting and associated hydrothermal activity in the proximal part was as intense as observed in 1989. Other than these active chimneys, diffusive shimmering vents and inactive chimneys were recognized along a NESW direction (Nakamura et al., 1989). Emission of $\mathrm{CO}_{2}$ dominated liquid bubbles were identified in the distal part of the Jade field at both ends of the chimney line, one of which was previously reported in Sakai et al. (1990b). At the southwestern end of the Jade field, a notable layered and consolidated structure plausibly composed of amorphous silica and native sulfur was localized in 2003, and named as "sulfur crust". In the vicinity of the sulfur crust, diffusive venting of hydrothermal fluid at $104^{\circ} \mathrm{C}$ associated with liquid $\mathrm{CO}_{2}$ bubbling was recognized in 2003, which was named as the "Biwako vent" (Fig. 1).

The Hakurei field is located at the bottom of the depression of the Izena Hole, at water depths of 1600-1610 m (Fig. 1). The northern part of the Hakurei field is located at about $3 \mathrm{~km}$ far from the Jade field in the southwestern direction. Hydrothermal activities were observed in an area of at least $500 \mathrm{~m} \times 300 \mathrm{~m}$, during our dive expeditions. Vigorous high temperature fluid venting in the Hakurei field was often associated with a complex chimney structure of more than 10 meters height and showing a well-developed flange structure. At "Dragon" chimney at the depth of $1600 \mathrm{~m}$ (Fig. 1), we observed effluent from the edges of the flange, which recorded the highest temperature ever of $326^{\circ} \mathrm{C}$ among the Hakurei field. The seafloor away from these complex chimney structures is covered with sandy and silty sediment (Kato et al., 1989). In some places, white-colored patched area and sulfur crust structure were recognized by visual observations.

\section{SAMPling AND ANALYTICAL METhods}

Fluid samples were collected during dive missions in 2003 (NT03-09 cruise), 2010 (NT10-17 cruise) and 2011 (NT11-15 cruise). Fluid sampling was conducted using WHATS sampler type JAM-3, which was developed for collecting fluid samples without loss of gas species (Saegusa et al., 2006). The sampler was installed on ROV Hyper Dolphin and controlled from an operator onboard R/V Natsushima. A platinum resistance thermometer at the end of the fluid inlet titanium tubing enabled temperature monitoring during collection of fluids. Plastic bag sampler (Kawagucci et al., 2011) was also used for venting fluid sampling. In addition, 2.5-L Niskin bottles were employed for the sampling of ambient seawater.

The fluid samples were processed as quickly as possible after ROV recovery. Aliquots for each specific analysis were drawn from the sampler using silicon rubber tubing. Measurement of $\mathrm{pH}$ and colorimetry for silica $\left(\mathrm{SiO}_{2}\right)$, ammonium $\left(\mathrm{NH}_{4}{ }^{+}\right)$, and hydrogen sulfide $\left(\mathrm{H}_{2} \mathrm{~S}\right)$ were conducted onboard following Gieskes et al. (1991) procedure. Subsamples were transferred into two polyethylene bottles after filtration using $0.2-\mu \mathrm{m}$ pore membrane filter. One of them, for cation analysis, was acidified to $\mathrm{pH}$ $<2$. The other, for anion analysis, was kept in a refrigerator and analyses carried out ashore. Sulfate $\left(\mathrm{SO}_{4}{ }^{2-}\right)$ concentration was analyzed by ion chromatography after 300 times dilution. Chloride $\left(\mathrm{Cl}^{-}\right)$concentration and alkalinity was determined by titrations (Gieskes et al., 1991). Concentration of cations was determined on flame emission spectrophotometry for potassium (K) and on ICPAES for boron (B), sodium (Na), lithium (Li), magnesium $(\mathrm{Mg})$, calcium $(\mathrm{Ca})$, barium $(\mathrm{Ba})$, iron $(\mathrm{Fe})$, manganese (Mn), and strontium (Sr) after 200 times dilution of the acidified aliquots. Total selenium (Se) concentration was analyzed through high performance liquid chromatography with fluorescence detection (Nakaguchi et al., 2004). Analytical errors for these chemical analyses, estimated from replicate analysis, were within $\pm 5 \%$ for the instrumental analyses and alkalinity determination, and within $\pm 0.5 \%$ for the chloride titration.

Fluid samples for gas analyses were obtained only in 2010. After recovery of the WHATS sampler, fluid in a stainless steel gas-tight bottle $(150 \mathrm{~mL})$ was immediately opened into a vacuum line $(\mathrm{ca} .1 .5 \mathrm{~L})$ to extract dissolved gas species. In the vacuum line, $\sim 2 \mathrm{ml}$ of reagent-grade solid sulphamic acid $\left(\mathrm{HOSO}_{2} \mathrm{NH}_{2}\right)$ was added to stimulate degassing, and $\sim 2 \mathrm{ml}$ of mercury chloride $\left(\mathrm{HgCl}_{2}\right)$ powder was added to fix sulphide as mercury sulfide $(\mathrm{HgS})$. After the degassing for over 10 minutes, the gas phase was collected in 50-mL stainless steel bottles for subsequent gas analyses. The degassed fluid sample was recovered and filtered using a $0.45-\mu \mathrm{m}$ pore membrane filter, which was provided for $\mathrm{Mg}$ and sulphur isotope ratio measurements.

Concentrations of molecular hydrogen $\left(\mathrm{H}_{2}\right)$, carbon dioxide $\left(\mathrm{CO}_{2}\right)$, methane $\left(\mathrm{CH}_{4}\right)$, carbon monoxide $(\mathrm{CO})$, and ethane $\left(\mathrm{C}_{2} \mathrm{H}_{6}\right)$ were determined by GC-HID analysis of the extracted gas phase, with errors of $10 \%$. Helium (He) concentration was determined by GC-TCD analysis utilizing argon as a carrier gas, with a $10 \%$ error. Carbon isotope ratio of $\mathrm{CO}_{2}$ was determined by continuous-flow isotope ratio mass spectrometry (Kawagucci et al., 2005 with some modification) with analytical errors of $0.5 \%$ 

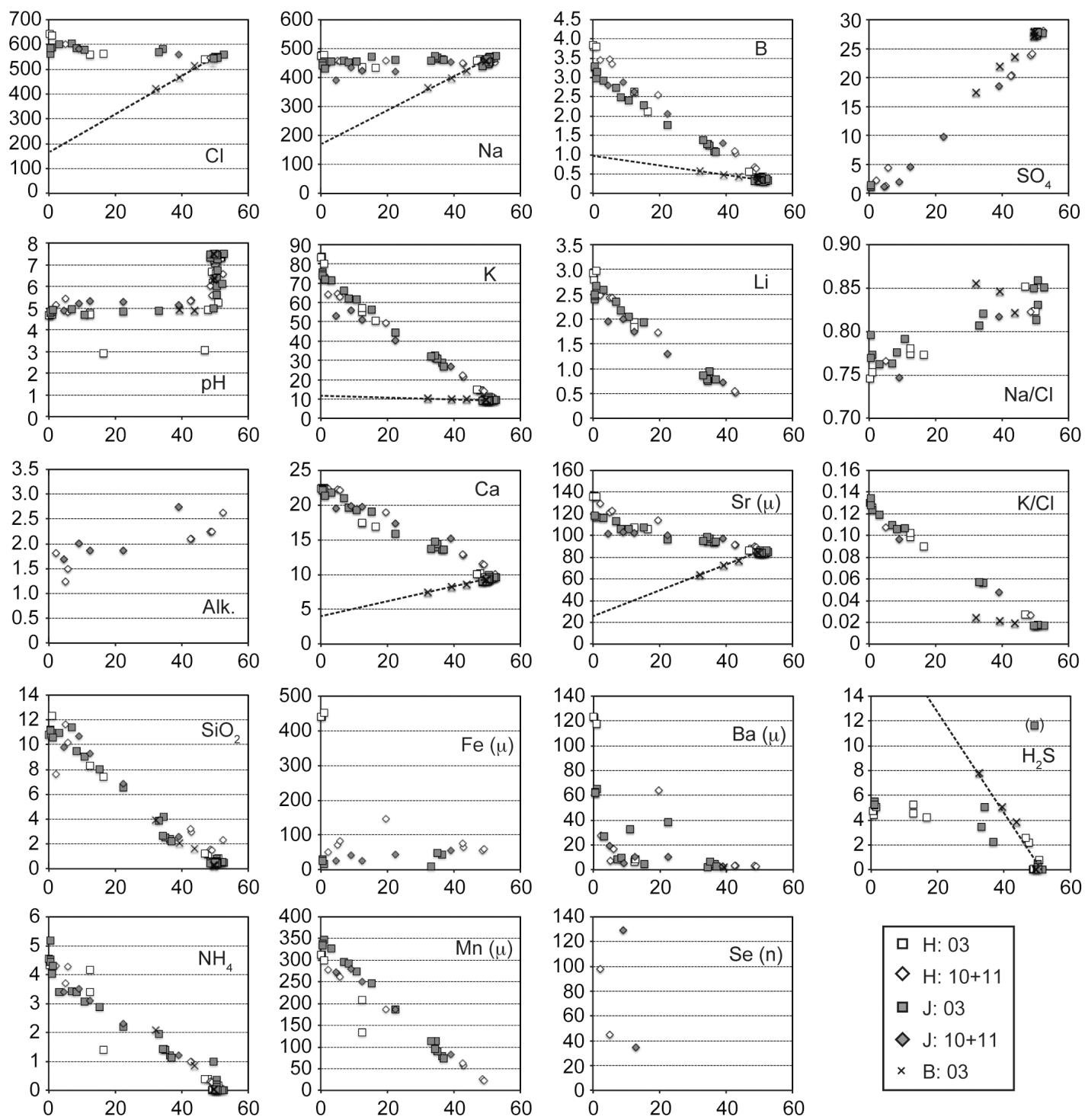

$\mathrm{Mg}(\mathrm{mmol} / \mathrm{kg})$

Fig. 2. Magnesium diagrams showing analytical results of elemental concentrations for all the studied samples. Open and grey symbols represent samples collected from the Hakurei and Jade fields, respectively. Square and diamond symbols represent samples collected in 2003 and 2010/2011, respectively. Cross symbol represents samples collected from the Biwako vent in 2003. Dashed lines represent linear regressions for the Biwako data set. Panels with signatures " $\mu$ )" and "( $n)$ " have units of $\mu M$ and $n M$ in $y$-axis, while those with no signature are in $m M$.

$(1 \sigma)$. Carbon and hydrogen isotope ratios of $\mathrm{CH}_{4}$ were determined by continuous-flow isotope ratio mass spectrometry (Popp et al., 1995; Umezawa et al., 2009 with some modification) with analytical errors of $0.5 \%$ and $5 \% \circ(1 \sigma)$, respectively. Hydrogen isotope ratio of $\mathrm{H}_{2}$ was determined by continuous-flow isotope ratio mass spectrometry with analytical error of 5\%o $(1 \sigma)$ (Kawagucci et al., 2010b). Helium isotope ratio was measured with a conventional noble gas mass spectrometer (Sano et al.,
2008). Hydrogen and oxygen isotope ratios of water $\left(\mathrm{H}_{2} \mathrm{O}\right)$ were determined by a wavelength-scanned cavity ring down spectroscopy analyzer (Liquid Water Isotope Analyzer, Los Gatos Research, Inc.) with analytical precision within $1.0 \%$ and $0.5 \% \circ(1 \sigma)$, respectively. Sulfur isotope ratios of mercury sulfides $(\mathrm{HgS})$ recovered from the degassed fluid sample were determined by EA/irMS (IsoPrime coupled with Euro Vector EA3000, GV Instruments). This ratio is considered equivalent to that of hy- 
Table 1. Elemental species composition of estimated hydrothermal fluid end-members of active hydrothermal fields in the Izena Hole

\begin{tabular}{|c|c|c|c|c|c|c|c|c|c|c|c|c|c|c|c|c|}
\hline Hydrothermal site & $\begin{array}{c}\text { Sampling } \\
\text { year }\end{array}$ & $\begin{array}{c}\text { Temp. } \\
{ }^{\circ} \mathrm{C}\end{array}$ & $\mathrm{pH}$ & $\begin{array}{c}\mathrm{Cl} \\
\mathrm{mM}\end{array}$ & $\begin{array}{c}\mathrm{Na} \\
\mathrm{mM}\end{array}$ & $\begin{array}{c}\mathrm{K} \\
\mathrm{mM}\end{array}$ & $\begin{array}{c}\mathrm{Li} \\
\mathrm{mM}\end{array}$ & $\begin{array}{c}\mathrm{Ca} \\
\mathrm{mM}\end{array}$ & $\begin{array}{c}\mathrm{Sr} \\
\mu \mathrm{M}\end{array}$ & $\begin{array}{l}\mathrm{Mn} \\
\mathrm{mM}\end{array}$ & $\begin{array}{c}\mathrm{B} \\
\mathrm{mM}\end{array}$ & $\begin{array}{c}\mathrm{NH}_{4} \\
\mathrm{mM}\end{array}$ & $\begin{array}{c}\mathrm{Si} \\
\mathrm{mM}\end{array}$ & $\begin{array}{l}\mathrm{H}_{2} \mathrm{~S} \\
\mathrm{mM}\end{array}$ & $\mathrm{Na} / \mathrm{Cl}$ & $\mathrm{K} / \mathrm{Cl}$ \\
\hline Hakurei & $2003-2011$ & 326 & 4.7 & 608 & 458 & 75 & 2.8 & 23 & 129 & 0.29 & 3.7 & 4.4 & 11.3 & 5.2 & 0.75 & 0.123 \\
\hline Jade & $2003-2011$ & 320 & 4.7 & 590 & 442 & 72 & 2.5 & 22 & 115 & 0.34 & 3.2 & 4.2 & 11.8 & 5.6 & 0.75 & 0.122 \\
\hline Jade [a] & 1989 & 320 & 4.7 & 550 & 425 & 72 & 2.5 & 22 & - & 0.11 & - & 5.0 & 12.9 & 13 & 0.77 & 0.131 \\
\hline Biwako & 2003-2011 & 104 & 4.8 & 167 & 173 & 12 & - & 4.3 & 27 & 一 & 1.0 & 5.0 & 11.0 & 23 & 1.04 & 0.072 \\
\hline Yonaguni IV & [b] & 325 & 5.7 & 614 & 416 & 86 & - & 23 & - & 1.1 & 3.9 & 14.7 & 11.3 & - & 0.68 & 0.140 \\
\hline Minami Ensei & [c] & 280 & 4.9 & 562 & 436 & 53 & 一 & 23 & 260 & 0.10 & - & 5.4 & 11.1 & 0.4 & 0.78 & 0.094 \\
\hline Hatoma & [d] & 240 & 5.2 & 381 & 285 & 55 & - & 17 & 62 & 0.48 & 3.3 & 7.2 & 12.0 & - & 0.75 & 0.144 \\
\hline Iheya North & [e] & 309 & 5.0 & 557 & 407 & 72 & - & 22 & 73 & 0.65 & - & 1.7 & 12.3 & - & 0.73 & 0.129 \\
\hline (seawater) & & & 7.5 & 540 & 460 & 10 & 0.03 & 11 & 91 & - & 0.43 & $<0.01$ & 0.1 & - & 0.85 & 0.019 \\
\hline
\end{tabular}

[a] Sakai et al. (1990a), Gamo et al. (1991). [b] Data for Lion vent, Suzuki et al. (2008). [c] Kawagucci et al. (2013) and references therein. [d] Kishida et al. (2004). [e] Kawagucci et al. (2011).

drogen sulfide $\left(\mathrm{H}_{2} \mathrm{~S}\right)$ dissolved in the original hydrothermal fluid. Following the previous study (Yamanaka et al., 2008), the mercury sulfide precipitation was oxidized using mixture of concentrated nitric acid and bromine (10:1 in volume), and sulfur was then precipitated as barium sulfate $\left(\mathrm{BaSO}_{4}\right)$ by addition of $0.5 \mathrm{M} \mathrm{BaCl}$ solution. Collected $\mathrm{BaSO}_{4}$ was wrapped within a tin capsule with $\mathrm{V}_{2} \mathrm{O}_{5}$ powder and directly subjected to the EA/irMS. Sulfur isotope ratio of the native sulfur samples was directly measured by EA/irMS, without treatment. Analytical precision for the sulfur isotope measurements is estimated as $0.2 \%$ o $(1 \sigma)$ (Yamanaka et al., 2008).

\section{RESUlTS}

Analytical results of elemental (ion) concentrations for all the studied samples are reported as twocomponent diagrams where concentration of each chemical species is plotted against the magnesium concentration (Fig. 2). In these so-called Mg diagrams, mixing between two end-members, namely hydrothermal fluid $([\mathrm{Mg}]=0 \mathrm{mM})$ and seawater $([\mathrm{Mg}]=54 \mathrm{mM})$ is expressed as a mixing line (Von Damm et al., 1985). In Fig. 2, samples are categorized into groups by sampling time, 2003 (03) and 2010/2011 (10), and by sampling sites, Hakurei field $(\mathrm{H})$, the proximal part of Jade field $(\mathrm{J})$, and Biwako vent located in the distal part of the Jade field (B).

The plots are likely to form good linear relationships in the $\mathrm{Mg}$ diagrams for each vent field regardless the sampling time. As for exceptions, $\mathrm{Fe}, \mathrm{Se}$ and $\mathrm{Ba}$ concentrations in Mg diagrams showed significant scatter, which are plausibly due to the non-conservative behavior (e.g., precipitation) of these species during sampling or postsampling processes. The good linear relationships in the $\mathrm{Mg}$ diagrams suggest that all the fluids from each vent site originate from a single hydrothermal fluid source.
No systematic difference is observed between the plots of 2003 and of 2010/2011, which suggests chemistry of the fluid source is stable for at least this duration. Chemical composition of the fluid source can be estimated from the $y$-intercept of the least-squares linear regression in the $\mathrm{Mg}$ diagrams. In the case that data points are too few to estimate regression, the end-member composition is assumed to be equal to that of the higher temperature fluid sample with $[\mathrm{Mg}]<5 \mathrm{mM}$. The calculated end-member chemical compositions for each vent field are summarized in Table 1.

Chemical composition of the high-temperature fluids from the Jade field was reported in a previous study (Sakai et al., 1990a), although with large uncertainty related to the sampling device used (Sakai et al., 1990a). As shown in Table 1, difference in concentrations of major species $(\mathrm{Cl}, \mathrm{Na}, \mathrm{K}, \mathrm{Ca}$ and $\mathrm{Si})$ measured in this study is within $10 \%$ of the estimated end-member composition determined previously (from the 1989 samples). This accordance suggests that high-temperature fluids from the Jade field have not changed significantly for this duration. Moreover, chemical composition of high-temperature fluids from the Hakurei field shows good similarity to that of the Jade fluid. On the other hand, six samples collected from the Biwako vent site in the distal part of the Jade field show clearly distinctive trend in the $\mathrm{Mg}$ diagrams from high temperature fluid samples in the proximal part of the Jade field (Fig. 2). Good linear relationship among the plots of the Biwako site provides the hydrothermal end-member chemical composition with little ambiguity. The Biwako fluid is represented by notably low $\mathrm{Cl}$ concentration $(167 \mathrm{mM})$, which is approximately one third of the seawater concentration (Table 1).

Gas geochemistry data are summarized in Table 2. Stable isotope ratios of carbon, hydrogen, oxygen, and sulfur are represented by the delta-notation in per-mil 
Table 2. Gas species composition of hydrothermal fluids from active hydrothermal fields in the Izena Hole (a) Analytical results of the studied samples

\begin{tabular}{lccccccccccccc}
\hline Site & $\begin{array}{c}\text { Sample } \\
\text { ID }\end{array}$ & $\begin{array}{c}\mathrm{Mg} \\
\mathrm{mM}\end{array}$ & $\begin{array}{c}\mathrm{CO}_{2} \\
\mathrm{mM}\end{array}$ & $\begin{array}{c}\delta^{13} \mathrm{C}\left(\mathrm{CO}_{2}\right) \\
\% 0\end{array}$ & $\begin{array}{c}\mathrm{CH}_{4} \\
\mathrm{mM}\end{array}$ & $\begin{array}{c}\delta^{13} \mathrm{C}\left(\mathrm{CH}_{4}\right) \\
\% o\end{array}$ & $\begin{array}{c}\delta \mathrm{D}\left(\mathrm{CH}_{4}\right) \\
\% o\end{array}$ & $\begin{array}{c}\mathrm{H}_{2} \\
\mathrm{mM}\end{array}$ & $\begin{array}{c}\delta \mathrm{D}\left(\mathrm{H}_{2}\right) \\
\% o\end{array}$ & $\begin{array}{c}\mathrm{C}_{2} \mathrm{H}_{6} \\
\mu \mathrm{M}\end{array}$ & $\begin{array}{c}\mathrm{CO} \\
\mu \mathrm{M}\end{array}$ & $\begin{array}{c}\mathrm{He} \\
\mu \mathrm{M}\end{array}$ & $\begin{array}{c}{ }^{3} \mathrm{He} /{ }^{4} \mathrm{He} \\
\mathrm{R}_{\mathrm{atm}}\end{array}$ \\
\hline Hakurei & $\# 1191$ & 9.9 & 124 & -6.2 & 5.6 & -32.1 & -113 & 1.17 & -379 & 2.04 & 52 & 0.44 & 5.81 \\
Hakurei & $\# 1187$ & 40.8 & n.a. & n.a. & 1.2 & -32.0 & -114 & 0.34 & -384 & n.d. & 23 & n.d. & n.a. \\
Jade & $\# 1184$ & 13.0 & 119 & -6.2 & 3.7 & -30.8 & -113 & 0.05 & -381 & 0.25 & 23 & 0.55 & 4.65 \\
\hline
\end{tabular}

n.a. = not analyzed, n.d. = not detected .

(b) Estimated hydrothermal fluid end-members

\begin{tabular}{|c|c|c|c|c|c|c|c|c|c|c|c|c|c|}
\hline Site & $\begin{array}{l}\mathrm{CO}_{2} \\
\mathrm{mM}\end{array}$ & $\begin{array}{c}\delta^{13} \mathrm{C}\left(\mathrm{CO}_{2}\right) \\
\% o\end{array}$ & $\begin{array}{l}\mathrm{CH}_{4} \\
\mathrm{mM}\end{array}$ & $\begin{array}{c}\delta^{13} \mathrm{C}\left(\mathrm{CH}_{4}\right) \\
\% 0\end{array}$ & $\begin{array}{c}\delta \mathrm{D}\left(\mathrm{CH}_{4}\right) \\
\% 0\end{array}$ & $\begin{array}{c}\mathrm{H}_{2} \\
\mathrm{mM}\end{array}$ & $\begin{array}{l}\mathrm{CO} \\
\mu \mathrm{M}\end{array}$ & $\begin{array}{l}\mathrm{He} \\
\mu \mathrm{M}\end{array}$ & $\begin{array}{c}{ }^{3} \mathrm{He} /{ }^{4} \mathrm{He} \\
\mathrm{R}_{\mathrm{atm}}\end{array}$ & $\mathrm{H}_{2} / \mathrm{CH}_{4}$ & $\mathrm{CH}_{4} / \mathrm{C}_{2} \mathrm{H}_{6}$ & $\begin{array}{c}\mathrm{CH}_{4} /{ }^{\beta} \mathrm{He}^{*} \\
\quad \times 10^{6}\end{array}$ & $\begin{array}{c}\mathrm{CO}_{2}{ }^{\beta} \mathrm{He}^{*} \\
\times 10^{9}\end{array}$ \\
\hline Hakurei & 151 & -6.2 & 6.8 & -32.1 & -113 & 1.4 & 63 & 0.53 & 5.81 & 0.21 & 2730 & 1434 & 32 \\
\hline Jade & 156 & -6.2 & 4.9 & -30.8 & -113 & 0.06 & 30 & 0.72 & 4.65 & 0.013 & 14900 & 761 & 25 \\
\hline Jade [a] & 209 & -4.9 & 7.1 & -40.7 & - & 0.05 & - & 0.89 & 6.5 & 0.007 & - & 920 & 26 \\
\hline Minami Ensei [b] & 42 & -5 & 2.3 & -25 & -105 & 0.04 & - & - & 7.0 & 0.017 & $>1710$ & - & - \\
\hline Iheya North [c] & 227 & -10 & 7.6 & -54.0 & -132 & 0.23 & - & - & 7.1 & 0.03 & $>3700$ & 一 & - \\
\hline
\end{tabular}

[a] Ishibashi et al. (1995). [b] Kawagucci et al. (2013). [c] Kawagucci et al. (2011).

*Helium isotope ratio was assumed as 6.5 for calculation.

scales against the international standards of VPDB, VSMOW, VSMOW, and CDT, respectively. Helium isotopic ratio $\left({ }^{3} \mathrm{He} /{ }^{4} \mathrm{He}\right)$ is normalized to that of the atmosphere of $1.39 \times 10^{-6}$. As a previous study demonstrated for the Jade field (Ishibashi et al., 1995), the high temperature fluids in both fields are characterized by very high concentrations in gas species. Concentration of $\mathrm{CO}_{2}$ which is the most dominant gas specie is about $150 \mathrm{mM}$ in these two sites. Concentrations of $\mathrm{CH}_{4}(6.8 \mathrm{mM}$ for the Hakurei fluid and $4.9 \mathrm{mM}$ for the Jade fluid) and $\mathrm{He}$ $(0.53$ and $0.72 \mu \mathrm{M})$ are also comparable between the two sites. Stable carbon and hydrogen isotope ratios of $\mathrm{CO}_{2}$, $\mathrm{CH}_{4}$ and $\mathrm{H}_{2}$ are mostly identical between the two sites: $\delta^{13} \mathrm{C}_{\mathrm{CO} 2}=-6.2 \% o, \delta^{13} \mathrm{C}_{\mathrm{CH} 4}=-32 \% o, \delta \mathrm{D}_{\mathrm{CH} 4}=-113 \%$, and $\delta \mathrm{D}_{\mathrm{H} 2}=-380 \%$ or the Hakurei fluid, and $\delta^{13} \mathrm{C}_{\mathrm{CO} 2}=$ $-6.2 \%, \delta^{13} \mathrm{C}_{\mathrm{CH} 4}=-31 \%, \delta \mathrm{D}_{\mathrm{CH} 4}=-113 \%$, and $\delta \mathrm{D}_{\mathrm{H} 2}=$ $-380 \%$ o for the Jade fluid. Isotope ratios of He show slight difference; ${ }^{3} \mathrm{He} /{ }^{4} \mathrm{He}=4.02 \pm 0.12 \mathrm{R}_{\mathrm{atm}}$ for the Jade field and $5.80 \pm 0.13 R_{a t m}$ for the Hakurei field. Contrary to this, $\mathrm{H}_{2}$ is notably enriched in the Hakurei fluid (1.4 mM) compared to the Jade fluid $(0.06 \mathrm{mM})$. Measured $\mathrm{C}_{2} \mathrm{H}_{6}$ concentration for the Hakurei fluid is also higher $(2 \mu \mathrm{M})$ than that for the Jade fluid $(0.3 \mu \mathrm{M})$. Sulfur isotopic composition of hydrogen sulfide shows higher diversity between sampling fields and times. $\delta^{34} \mathrm{~S}$ values of $\mathrm{H}_{2} \mathrm{~S}$ of the high temperature fluids in the Jade field are from $+3.6 \%$ to $+6.8 \%$ in 2010 , which are somehow lower than those in 1989 (from +7.4\%o to +7.7\%o: Gamo et al., 1991). In the Hakurei field, $\delta^{34} \mathrm{~S}$ values of hydrogen sulfide of high temperature fluids are from $+5.5 \%$ to $+7.8 \%$ o. Iso- tope ratios of $\mathrm{H}_{2} \mathrm{O}$ of the high temperature fluids were analyzed for only a few samples; $\delta \mathrm{D}_{\mathrm{H} 2 \mathrm{O}}=-0.3 \%$ and $\delta^{18} \mathrm{O}_{\mathrm{H} 2 \mathrm{O}}=+1.8 \%$ for the Jade field $(n=1)$ and $\delta \mathrm{D}_{\mathrm{H} 2 \mathrm{O}}=$ $-0.6 \%$ and $\delta^{18} \mathrm{O}_{\mathrm{H} 2 \mathrm{O}}=+1.6 \%$ o for the Hakurei field (averaged values from $n=4$ ).

\section{Discussion}

Chemistry of high temperature hydrothermal fluids from the Izena Hole

The high temperature fluids collected from both the Jade and Hakurei fields showed strong similarities in fluid geochemistry. $\mathrm{SiO}_{2}$ concentrations were 11.3 and $12.0 \mathrm{mM}$ in the Jade and Hakurei fluids. These values correspond to the expected quartz solubility concentrations at pressure and temperature conditions of each site (Von Damm et al., 1991). The moderate acidity of both the Jade and Hakurei fluids $(\mathrm{pH}=\sim 4.7)$ was comparable to those in other hydrothermal fields in the Okinawa Trough (Table 1). Alkalinity was about $1.5 \mathrm{mM}$, which suggests being neutralized at high temperature condition. This rather neutral $\mathrm{pH}$ is contrary to geochemical characteristics of hydrothermal fields in the Manus Basin, which is considered as a back arc basin in a rifting tectonic stage as well as the Okinawa Trough. However active hydrothermal fields in the Manus Basin are located in a sediment-poor environment compared to the Okinawa Through, because they are located far from any continents. Strong acidity was remarkable in high temperature fluid in the Pacmanus field (Reeves et al., 2011) and low temperature fluid in 
the Desmos field (Gamo et al., 1997). These previous studies demonstrated the acidity is attributed to significant contribution of magmatic volatiles, especially $\mathrm{SO}_{2}$ into the hydrothermal fluids (Reeves et al., 2011). On the other hand, contribution of magmatic volatile species into hydrothermal fluid was also notable in the Jade and Hakurei fluids as discussed later. Therefore, to explain the discrepancies in the $\mathrm{pH}$ between the Manus Basin fluids and those of the Jade and Hakurei fluids, fluidsediment interactions could be the factor controlling the $\mathrm{pH}$ as well as dissolved gas speices.

Chemical compositions of major ion species $(\mathrm{Cl}, \mathrm{Na}$, $\mathrm{K}$, and $\mathrm{Ca}$ ) in the Jade and Hakurei fluids were very similar. The hydrothermal end-member $\mathrm{Cl}$ concentration as the $y$-intercept of the $\mathrm{Mg}-\mathrm{Cl}$ diagram was estimated as $590 \mathrm{mM}$ for the Jade fluid, while the observed maximum was $604 \mathrm{mM}$. For the Hakurei fluid, the end-member $\mathrm{Cl}$ concentration was estimated as $608 \mathrm{mM}$, while the observed maximum was $643 \mathrm{mM}$. Both $\mathrm{Cl}$ concentrations were higher than that of seawater $(=540 \mathrm{mM})$. Sodium concentrations were $442 \mathrm{mM}$ and $458 \mathrm{mM}$ in the Jade and Hakurei fluids, respectively. Molar ratios of $\mathrm{Na} / \mathrm{Cl}$ were in the range from 0.75 to 0.80 for both fluids, which were substantially lower than that of ambient seawater $(=0.86)$. This lower $\mathrm{Na} / \mathrm{Cl}$ ratio would be attributed to $\mathrm{Na}$ uptake during fluid-mineral interactions involving plagioclase minerals, as proposed by Reeves et al. (2011). Concentrations of $\mathrm{Ca}$ were around $22 \mathrm{mM}$ for both fluids, and concentrations of $\mathrm{K}$ were $72-75 \mathrm{mM}$. Both $\mathrm{Ca}$ and $\mathrm{K}$ concentrations were much higher than those of seawater. Enrichment in $\mathrm{K}$ for high temperature fluid was one of the common characteristics observed in hydrothermal fields in the Okinawa Trough (Table 1). Endmember $\mathrm{K} / \mathrm{Cl}$ ratios were 0.12 for both the Jade and Hakurei fields, which was comparable for $\mathrm{K} / \mathrm{Cl}$ ratios found in the Yonaguni IV field (=0.14; Suzuki et al., 2008), Hatoma field (=0.14; Kishida et al., 2004) and Iheya North field ( $=0.13$; Kawagucci et al., 2011). These ratios are clearly higher than $\mathrm{K} / \mathrm{Cl}$ ratios found in typical MOR hydrothermal fields (around 0.05; Von Damm, 1995). The high $\mathrm{K} / \mathrm{Cl}$ ratios of high temperature fluids from the Okinawa Trough are likely to reflect high K contents in surrounding rocks with which fluid interacts during hydrothermal circulation (Sakai et al., 1990a).

Also for the minor element compositions, no large discrepancies were recognized between the Jade and Hakurei fluids. Concentrations of Li were from 2.5 to 2.7 $\mathrm{mM}$ and concentrations of $\mathrm{B}$ from 3.2 to $3.7 \mathrm{mM}$ for high temperature fluids. These concentrations are significantly higher than those in typical MOR fluids $(\mathrm{Li}=0.5-1.5$ $\mathrm{mM}$ and $\mathrm{B}=0.5-1.0 \mathrm{mM}$; Von Damm, 1995). Since these concentrations are also higher than those of high temperature fluids collected from the Manus Basin (Reeves et al., 2011), contribution from fluid-sediment interac- tions could be important. Concentrations of Se around $120 \mathrm{nM}$ and of $\mathrm{Mn}$ around $300 \mu \mathrm{M}$ were also comparable to the concentration range among hydrothermal fields in the Okinawa Trough.

Gas concentrations for the Jade and Hakurei fluids show also some similarity, but with a few notable exceptions. Concentrations of $\mathrm{CO}_{2}$ and $\mathrm{He}$, as well as carbon and helium isotope ratios were similar between the two fields. As discussed in a previous study (Ishibashi et al., 1995), the carbon and helium systematics of the high temperature fluids are attributed to significant contribution of volatile species of magmatic origin. Calculated $\mathrm{CO}_{2} /$ ${ }^{3} \mathrm{He}$ ratios of $(20-30) \times 10^{9}$ can be interpreted as reflecting molar ratio of magmatic fluid generally observed in arc-backarc settings. Concentrations of $\mathrm{H}_{2} \mathrm{~S}$ of the hightemperature fluid were around $5-6 \mathrm{mM}$ in the Jade and Hakurei fields, and concentrations of $\mathrm{CH}_{4}$ were 4-7 mM for both high-temperature fluids. It is notable to find no large discrepancy for concentrations and isotope ratios of $\mathrm{CH}_{4}$ and $\mathrm{H}_{2} \mathrm{~S}$ between these two fluids, since these species derive from various sources during fluid-sediment interactions at the recharge zone (Kawagucci et al., 2013). Distinctive difference was found only in concentrations of $\mathrm{H}_{2}$ and $\mathrm{C}_{2} \mathrm{H}_{6}$, which will be discussed later.

In summary, chemical composition of the high temperature fluids collected from the Jade field and Hakurei field were very similar with exception of a few minor species. This similarity could be explained by a model in which venting fluids are derived from the same fluid reservoir beneath the seafloor. The highly similarities in gas geochemistry supports the idea that hydrothermal activities in the Jade field and Hakurei field shares a common hydrothermal circulation system at depth. Similarities in magmatic species $\left(\mathrm{CO}_{2}\right.$ and $\left.\mathrm{He}\right)$ imply that a single magma beneath the Izena Hole acts as a heat source, which contributes also magmatic volatiles into the fluid circulation system. Similarities in minor gas species $\left(\mathrm{CH}_{4}\right.$ and $\left.\mathrm{H}_{2} \mathrm{~S}\right)$ are well explained by a common fluid circulation system sharing at least the recharge zone. This model is reasonable considering that the distance between the two fields is about $3 \mathrm{~km}$. Beneath the Jade fields, a previous heat flow study demonstrated the existence of a heat source at very shallow depth (a few hundred meters), which would be attributed to an intruded dyke (Kinoshita and Yamano, 1997). The hydrothermal activity in the Jade field may be considered as a satellite activity, while the Hakurei field may represent one of the main activities of the hydrothermal system in the Izena Hole.

\section{Intra-field diversity in fluid chemistry caused by phase separation}

We found distinctive chemistry between the low temperature fluid collected from the Biwako site in the distal part of the Jade field (called as the Biwako fluid hereaf- 
ter) and the high temperature fluids collected from the proximal part of the Jade field (called as the Jade fluid hereafter). $\mathrm{Cl}$ concentration of the estimated hydrothermal end-member of $167 \mathrm{mM}$ for the Biwako fluid was approximately one third of seawater level. Along with $\mathrm{Cl}$, concentrations of $\mathrm{Na}(=173 \mathrm{mM}), \mathrm{K}(=11.9 \mathrm{mM})$ and $\mathrm{Ca}$ $(=4.3 \mathrm{mM})$ in the Biwako fluid were close to one third of the level of the Jade fluids (Table 1). On the other hand, enrichment in $\mathrm{H}_{2} \mathrm{~S}(=23 \mathrm{mM})$ and comparable concentrations of $\mathrm{NH}_{4}{ }^{+}(=5.0 \mathrm{mM})$ and $\mathrm{SiO}_{2}(=11.0 \mathrm{mM})$ compared with the Jade fluid are notable.

Proportional variation of major ion concentrations between the high and low temperature fluids from the Jade field strongly suggests that the intra-field variation is caused by phase separation beneath the seafloor. A previous study on fluid inclusions of sulfide/sulfate ore deposits collected from the proximal part of the Jade field demonstrated that phase separation occurred at 1500 to $2000 \mathrm{~m}$ water depth, based on varying salinities of the fluid inclusions (Lüders et al., 2001). Phase separation of hydrothermal fluids in such subcritical condition forms the vapor phase of substantially low $\mathrm{Cl}$ concentration and the liquid phase which $\mathrm{Cl}$ concentration is slightly higher than that of seawater. Dissolved ion species are distributed preferably into the liquid phase, while volatile species into the vapor phase (Butterfield et al., 2003). The low concentrations of major ion species $(\mathrm{Cl}, \mathrm{Na}, \mathrm{K}$, and $\mathrm{Ca}$ ) and high $\mathrm{H}_{2} \mathrm{~S}$ concentrations are attributed to that the low temperature Biwako fluid is dominantly composed of the vapor-phase of the hydrothermal fluid. On the other hand, the Jade fluid may be basically composed of the remaining liquid-phase of the original hydrothermal fluid, because it shows $\sim 10 \%$ higher $\mathrm{Cl}$ concentration than seawater. Comparable $\mathrm{SiO}_{2}$ concentrations between these two fluids may be attributed to no preferential distribution of silica due to electrically-neutral chemical speciation or quick dissolution of silicate minerals just prior to venting of the hydrothermal fluid. If phase separation completely controls the observed diversity of fluid chemistry, cation/anion ratio should be identical in these two fluids. However, the Biwako fluid showed slightly higher $\mathrm{Na} / \mathrm{Cl}$ ratio and lower $\mathrm{K} / \mathrm{Cl}$ ratio than those of the Jade fluid. This disagreement may be a result of the quick dissolution of silicate minerals or the involvement of seawater just prior to the hydrothermal fluid venting.

Formation of liquid $\mathrm{CO}_{2}$ bubbles and sulfur crust within the surface sediment were noticed in the distal part of the Jade field. As demonstrated in a previous study in the Yonaguni IV field (Konno et al., 2006), formation of liquid $\mathrm{CO}_{2}$ bubble would be explained by accumulation of $\mathrm{CO}_{2}$ delivered by the vapor-phase of the hydrothermal fluid. In similar way, formation of the sulfur crust would be related to the high $\mathrm{H}_{2} \mathrm{~S}$ concentration of the Biwako fluid. Range of sulfur isotope ratios of the sulfur crust from $+5.6 \%$ to $+6.3 \%$ overlaps with that of the hydrogen sulfide dissolved in the Jade high temperature fluid (from $+3.6 \%$ o to $+7.8 \%$ ). This agreement may support the idea of a hydrothermal origin of the sulfur crust, although we have no sulfur isotope data for the Biwako fluid to confirm this hypothesis. Contribution of microbial reduction of seawater sulfate may be alternative process to contribute formation of the sulfur crust. It is reasonable to expect abundant $\mathrm{CH}_{4}$ in the Biwako fluid due to phase separation (again despite of no data), which could stimulate microbial reduction of seawater sulfate $\left(\delta^{34} \mathrm{~S}=+20 \%\right.$ o within the sediment. Since microbial sulfate reduction generally generates approximately $10-30 \%{ }^{34} \mathrm{~S}$-depleted sulfide relative to the substrate sulfate, the observed sulfur isotope (from $+5.6 \%$ o to $+6.3 \%$ ) can be interpreted also as microbial process, although $\mathrm{SO}_{4}{ }^{2-}$ concentration of the seawater $(=28 \mathrm{mM})$ would limit availability as a sulfur source. On the other hand, input of $\mathrm{SO}_{2}$ derived directly from the magmatic volatile is excluded, because the disproportionation of $\mathrm{SO}_{2}$ induces native sulfur of more ${ }^{34} \mathrm{~S}$-depleted isotope ratio (Kusakabe et al., 2000). Based on the obtained data, plausible explanation for the significantly high $\mathrm{H}_{2} \mathrm{~S}$ concentration of the Biwako fluid (23 $\mathrm{mM}$ ) is a combination of hydrothermal source and effect of the microbial sulfate reduction. Further studies on sulfur and carbon cycles in the low-temperature hydrothermal environment in the distal part of a hydrothermal field are required. Occurrence of sulfur crusts was located also in the Hakurei field, and the sulfur isotope ratio was from $+9.2 \%$ to $+10.6 \%$. This result implies similar phase separation process may occur (or have occurred) beneath the Hakurei field, although no evidence was observed.

Similar intra-field variation of fluid chemistry has been identified in other hydrothermal fields in the Okinawa Trough, such as the Iheya-North field (Nakagawa et al., 2005; Kawagucci et al., 2011) and the Yonaguni IV field (Konno et al., 2006; Suzuki et al., 2008). As demonstrated in these previous studies, geographical distribution of $\mathrm{Cl}$ rich fluid vents and $\mathrm{Cl}$-depleted fluid vents is likely similar to the distribution of fluid emanations observed in onland geothermal fields. Venting fluid of the highest temperature located in the center of the active hydrothermal field is usually revealed as Cl-rich chemistry. Contrary to such vigorous venting in the proximal part, fluid venting in the distal part is often diffusive, of low temperature and of Cl-depleted chemistry. Our observation in the Jade field recognized common geographical distribution. The Cl-depleted venting of $104^{\circ} \mathrm{C}$ at the Biwako vent site was located in the distal part of the Jade filed, about 400 meters apart from the activity center. Such diffusive emanation could be an analogue to as acid-sulfate type vapor emanation in a geothermal system. This geographical distribution is accordance with the model that hydrothermal activity in the Jade field is driven by an intruded dyke. 


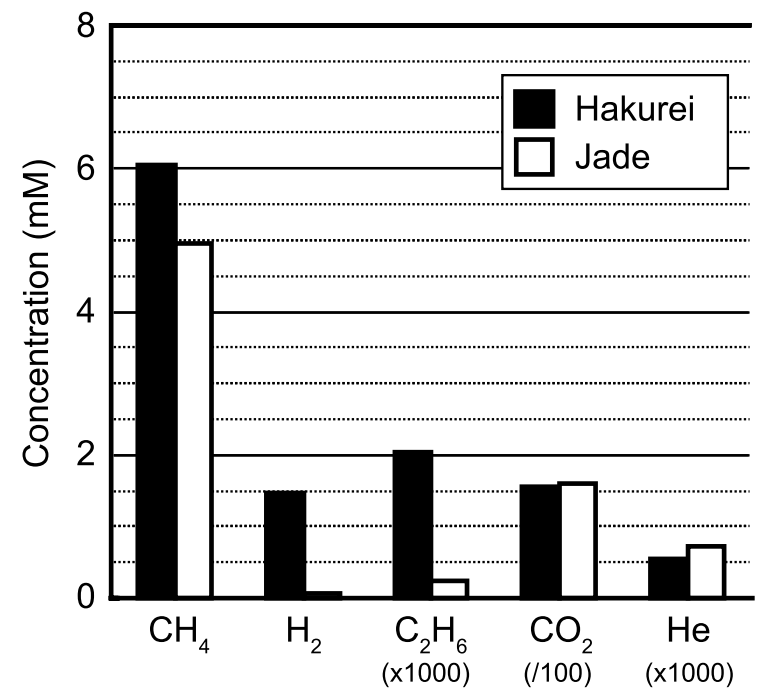

Fig. 3. Comparison of gas concentrations of hydrothermal fluids collected from the Hakurei and Jade fields.

Intrusion of a heat source of a small size could stimulate phase separation and segregation of the hydrothermal fluid.

Intra-field diversity in minor gas chemistry caused by fluid-sediment interactions

The exceptional difference between fluid chemistry of the Jade and Hakurei fields was recognized in composition of minor gas species such as $\mathrm{H}_{2}$ and $\mathrm{C}_{2} \mathrm{H}_{6}$. Concentration of $\mathrm{H}_{2}$ of the Hakurei fluid was more than one order higher than that of the Jade fluid (Fig. 3). This difference is in agreement with the chemical signature of the hydrothermal plumes above these fields; an order of magnitude higher $\mathrm{H}_{2} / \mathrm{CH}_{4}$ ratio in water column above the Hakurei field than the Jade field (Kawagucci et al., 2010a).

Concentration of $\mathrm{H}_{2}$ in hydrothermal fluids is considered to be primarily controlled by redox condition of the fluid reservoir. In case the surrounding rocks are silicic volcanic material, $\mathrm{H}_{2}$ concentration is expected to be less than $0.1 \mathrm{mM}$ (Kawagucci et al., 2013). Indeed, the observed $\mathrm{H}_{2}$ concentration of the Jade fluid was $0.06 \mathrm{mM}$. Increase of contribution from magmatic volatiles derived from rather oxic silicic magma would not account for the high $\mathrm{H}_{2}$ concentration of the Hakurei fluid, although enrichment in $\mathrm{H}_{2}$ in the periods following the magmatic event was observed in some hydrothermal fields in the mid-oceanic ridge setting (e.g., Haase et al., 2007). The high $\mathrm{H}_{2}$ concentration in the Hakurei fluid cannot be explained by phase separation, because the $\mathrm{Cl}$-rich chemistry suggests it experienced loss of the vapor phase. Phase separation can result in increase of $\mathrm{H}_{2}$ concentration in the vapor phase as demonstrated in the Yonaguni IV field

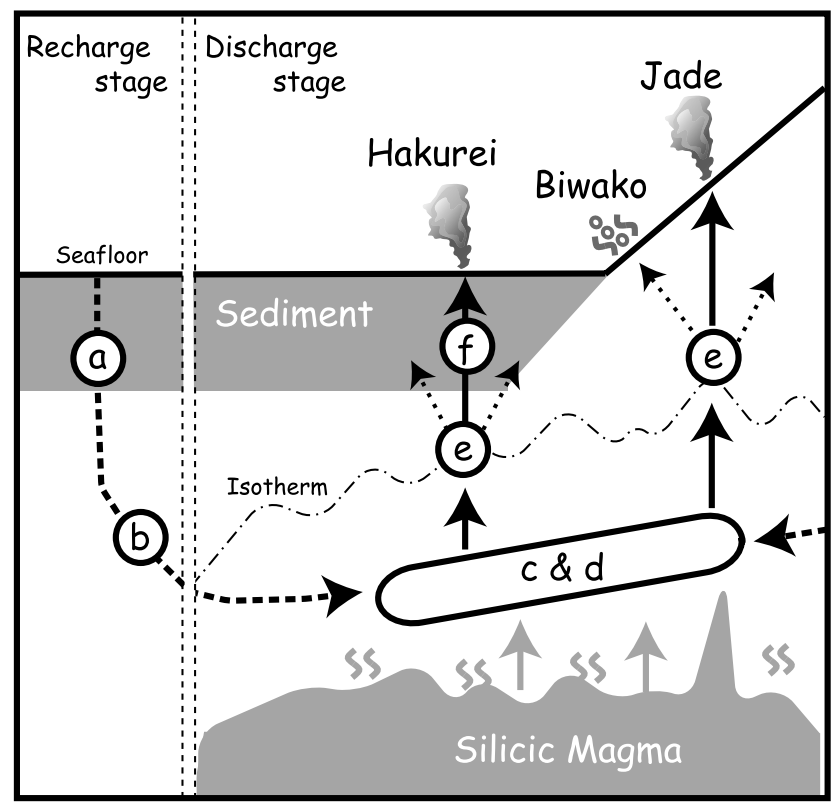

Fig. 4. Schematic cartoon illustrating the geochemical processes during the fluid circulation at the Izena Hole, which follows the original cartoon proposed by Reeves et al. (2011). a: low temperature water/rock reactions and involvement of organic-derived species at the recharge zone, $b$ : high temperature reactions at the reaction zone, $c$ : involvement of magmatic volatiles in the vicinity of the magma intrusion, $d$ : high temperature reactions to attain equilibrium in the fluid reservoir (reaction zone), e: phase separation (and segregation) during fluid ascent in the discharge zone, f: fluid-sediment interaction including thermal degradation of organic matter in the discharge zone.

(Konno et al., 2006), but would decrease $\mathrm{H}_{2}$ concentration in the residual liquid phase. Microbial fermentation is another potential $\mathrm{H}_{2}$ source, however the observed $\delta \mathrm{D}_{\mathrm{H} 2}$ value of $-380 \%$ suggesting that the fluid temperature above $300^{\circ} \mathrm{C}$ (Kawagucci et al., 2010b) is not in agreement with a contribution from such microbial process. Geological productions of $\mathrm{H}_{2}$ by water radiolysis (Lin et $a l ., 2005)$ and mechano-chemical reaction associated with fault activity (Kita et al., 1982; Hirose et al., 2011) have been proposed, but negligible in this case due to their weak and intermittent occurrence.

The most likely process to cause $\mathrm{H}_{2}$ enrichment in the Hakurei fluid is thermal degradation of sedimentary organic matter during the fluid upwelling (Seewald et al., 1994; Cruse and Seewald, 2006), as pointed out in the previous plume study (Kawagucci et al., 2010a). This process could be represented by a general reaction of hydrocarbons degradation as following,

$$
\mathrm{R}-\mathrm{CH}_{2} \mathrm{CH}_{2} \mathrm{CH}_{3}+4 \mathrm{H}_{2} \mathrm{O}=\mathrm{R}+2 \mathrm{CO}_{2}+\mathrm{CH}_{4}+5 \mathrm{H}_{2}
$$


where $\mathrm{R}$ is some hydrocarbon moiety (Seewald, 2003). Considering stoichiometry of this reaction, the observed differences between the Hakurei fluid and Jade fluid would be considered as evidence for the thermal degradation. Hydrocarbon composition of the Hakurei fluid was significantly enriched in ethane $\left(\mathrm{C}_{1} / \mathrm{C}_{2+}\right.$ ratio $\left.=2700\right)$ compared to the Jade fluid $\left(\mathrm{C}_{1} / \mathrm{C}_{2+}\right.$ ratio $\left.=14900\right)$, and $\mathrm{CH}_{4} /{ }^{3} \mathrm{He}$ ratio of the Hakurei fluid $\left(1410 \times 10^{6}\right)$ is higher than that of the Jade fluid $\left(750 \times 10^{6}\right)$. Although $\mathrm{CO}_{2}$ should be also produced during the thermal degradation as reported for other sediment-hosted hydrothermal system (Cruse and Seewald, 2006), overwhelming abundance of the magmatic $\mathrm{CO}_{2}$ prevents detection of difference neither in $\mathrm{CO}_{2}$ concentrations nor carbon isotope ratios.

As discussed previously, the Jade and Hakurei fluids are likely to share a common reservoir, which means that they share a common fluid circulation system at the recharge and reaction zones. Therefore, the distinctive minor gas composition should reflect process during fluid upwelling at the discharge zone. Because organic-derived species such as $\mathrm{CH}_{4}$ and $\mathrm{NH}_{4}{ }^{+}$would be involved into the hydrothermal fluid by microbiological activity during fluid-sediment interactions at the recharge zone (Kawagucci et al., 2013), effect of thermal degradation would not obviously appear in concentration of these species. Distinguishable difference was recognized specifically in concentrations of a few minor gas species such as $\mathrm{H}_{2}$ and $\mathrm{C}_{2} \mathrm{H}_{6}$ which is sensitive to thermal degradation of organic matter.

As described in the geological background section, observations during dive expeditions revealed different geological environments for the Jade and the Hakurei field. The Jade field is located on the slope where tuff breccia and woody pumice were often observed as exposed outcrop, whereas the Hakurei fields is located on the bottom seafloor of the depression. Here, the seafloor is covered with sediment except for the hydrothermal mounds. A thick sediment layer of more than 150 meters was recognized by a previous geophysical investigation (Y. Nakamura, personal communication). It is reasonable to expect that organic-derived species are added during upwelling of the high temperature fluid through such a thick sediment layer.

\section{CONCLUSION}

This study reports chemistry of hydrothermal fluids collected from the Jade and Hakurei fields both located in the Izena Hole, the middle Okinawa Trough. Their chemical characteristics are attributed to various geochemical processes during the fluid circulation, which are summarized in a schematic cartoon (Fig. 4). Fluid chemistry recognized in these two sites was common to other hydrothermal fields in the Okinawa Trough, which is explained by primary control by fluid interactions with surrounding silicic rocks. High similarity in chemical composition of major ions and gas species between these fluids suggests that they are derived from the same reservoir and share a common fluid circulation system. Whereas, diversity of geochemistry in the Jade and Hakurei hydrothermal fluids is attributed to chemical modification during fluid upwelling at the discharge zone. Intra-field diversity was found between the high temperature fluid at the proximal part and low temperature fluid in the distal part of the Jade field. Proportional variation of major ion concentrations is attributed to phase separation during fluid upwelling from the reservoir. Diffusive emanation of low temperature and vapor-rich fluid in the distal part is commonly observed in other hydrothermal fields in the Okinawa Trough. Another diversity of fluid chemistry was noted in the concentration of minor gas species between the high temperature fluids collected from the Jade and Hakurei fields. Enrichment in a few minor gas species in the Hakurei fluid is attributed to contribution from thermal gradation of organic matter during fluid upwelling through a thick sediment layer. The observed similarity and diversity in fluid chemistry are in agreement with a model based on geological and geophysical observations; the hydrothermal activity in the Jade field is supported by a satellite system related to an intruded dyke, while the Hakurei field is supported by a main fluid circulation system possibly located beneath thick sediment layer. This study shed light on importance of the Izena Hole as a natural laboratory for studying subseafloor processes at the discharge zone, by which chemical characteristics of hydrothermal activity are substantially affected.

Acknowledgments-We are grateful to the Hyper Dolphin operation team members and Captain and crew of $\mathrm{R} / \mathrm{V}$ Natsushima for their skillful operation during the dive missions. We appreciate onboard scientists of the NT03-09, NT10-17, and NT11-15 cruises for their kind collaboration during the sampling. We appreciate Drs. Naoto Takahata and Yuji Sano for their support during the helium isotope measurement in Atmosphere and Ocean Research Institute, The University of Tokyo. The earlier version of the manuscript was improved by constructive comments and suggestions by two anonymous reviewers. This study was partially supported by the "TAIGA project," which was funded by a Grant-in-Aid for Scientific Research on Innovative Areas (No. 20109004 and 20109005) from the Ministry of Education, Culture, Sports, Science and Technology (MEXT), Japan.

\section{REFERENCES}

Butterfield, D. A., Seyfried, W. E. Jr. and Lilley, M. D. (2003) Composition and evolution of hydrothermal fluids. Energy and Mass Transfer in Marine Hydrothermal Systems (Halbach, P. E., Tunnicliffe, V. and Hein, J. R., eds.), 124- 
161, Dahlem University Press, Germany.

Cruse, A. M. and Seewald, J. S. (2006) Geochemistry of lowmolecular weight hydrocarbons in hydrothermal fluids from Middle Valley, northern Juan de Fuca Ridge. Geochim. Cosmochim. Acta 70, 2073-2092.

Gamo, T., Sakai, H., Kim, E.-S., Shitashima, K. and Ishibashi, J. (1991) High alkalinity due to sulfate reduction in the CLAM hydrothermal field, Okinawa Trough. Earth Planet. Sci. Lett. 107, 328-338.

Gamo, T., Okamura, K., Charlou, J. L., Urabe, T., Auzende, J. M., Ishibashi, J., Shitashima, K., Chiba, H. and Shipboard Scientific Party (1997) Acidic and sulfate-rich hydrothermal fluids from the Manus back-arc basin, Papua New Guinea. Geology 25, 139-142.

Gamo, T., Ishibashi, J., Tsunogai, U., Okamura, K. and Chiba, H. (2006) Unique geochemistry of submarine hydrothermal fluids from arc-back-arc settings of the Western Pacific. Back-arc Spreading Systems: Geological, Biological, Chemical, and Physical Interactions (Christie, D. M., Fisher, C. R., Lee, S.-M. and Givens, S., eds.), 147-161.

German, C. R. and Von Damm, K. L. (2004) Hydrothermal processes. The Oceans and Marine Geochemistry (Holland, H. D. and Turekian, K. K., eds.), 181-222.

Gieskes, J. M., Gamo, T. and Brumsack, H. (1991) Chemical methods for interstitial water analysis aboard JOIDES Resolution. ODP Tech. Note No. 15.

Haase, K. M., Petersen, S., Koschinsky, A., Seifert, R., Devey, C. W., Keir, R., Lackschewitz, K. S., Melchert, B., Perner, M., Schmale, O., Süling, J., Dubilier, N., Zielinski, F., Fretzdorff, S., Garbe-Schönberg, D., Westernströer, U., German, C. R., Shank, T. M., Yoerger, D., Giere, O., Kuever, J., Marbler, H., Mawick, J., Mertens, C., Stöber, U., Walter, M., Ostertag-Henning, C., Paulick, H., Peters, M., Strauss, H., Sander, S., Stecher, J., Warmuth, M. and Weber, S. (2007) Young volcanism and related hydrothermal activity at $5^{\circ} \mathrm{S}$ on the slow-spreading southern Mid-Atlantic Ridge. Geochem. Geophys. Geosyst. 8, Q11002.

Halbach, P., Nakamura, K.-I., Wahsner, M., Lange, J., Sakai, H., Käselitz, L., Hannsen, R.-D., Yamano, M., Post, J., Prause, B., Seiffert, R., Michaelis, W., Teichmann, F., Kinoshita, M., Märten, A., Ishibashi, J., Czerwinski, S. and Blum, N. (1989) Probable modern analogue of Kuroko-type massive sulphide deposits in the Okinawa Trough back-arc basin. Nature 338, 496-499.

Halbach, P., Pracejus, B. and Märten, A. (1993) Geology and mineralogy of massive sulfide ores from the Central Okinawa Trough, Japan. Econ. Geol. 88, 2210-2225.

Hirose, T., Kawagucci, S. and Suzuki, K. (2011) Mechanoradical $\mathrm{H}_{2}$ generation during simulated faulting: Implications for an earthquake-driven subsurface biosphere. Geophys. Res. Lett. 38, L17303.

Ishibashi, J., Sano, Y., Wakita, H., Gamo, T., Tsutsumi, M. and Sakai, H. (1995) Helium and carbon geochemistry of hydrothermal fluids from the Mid-Okinawa Trough Back Arc Basin, southwest of Japan. Chem. Geol. 123, 1-15.

Kato, Y. (1990) Geology and topography on the ridge south of the active hydrothermal deposits of the Izena Hole-the results of diving survey in 1989-. JAMSTEC Deepsea Research 6, 27-31 (in Japanese with English abstract).
Kato, Y., Nakamura, K., Iwabuchi, Y., Hashimoto, J. and Kaneko, Y. (1989) Geology and topography in the Izena Hole of the middle Okinawa Trough - the results of diving surveys in 1987 and 1988-. JAMSTEC Deepsea Research 5, 163-182 (in Japanese with English abstract).

Kawagucci, S., Tsunogai, U., Kudo, S., Nakagawa, F., Honda, H., Aoki, S., Nakazawa, T. and Gamo, T. (2005) An analytical system for determining $\delta^{17} \mathrm{O}$ in $\mathrm{CO}_{2}$ using continuous flow-isotope ratio MS. Anal. Chem. 77, 4509-4514.

Kawagucci, S., Shirai, K., Lan, T. F., Takahata, N., Tsunogai, U., Sano, Y. and Gamo, T. (2010a) Gas geochemical characteristics of hydrothermal plumes at the HAKUREI and JADE vent sites, the Izena Cauldron, Okinawa Trough. Geochem. J. 44, 507-518.

Kawagucci, S., Toki, T., Ishibachi, J., Takai, K., Ito, M., Oomori, T. and Gamo, T. (2010b) Isotopic variation of molecular hydrogen in $20-375^{\circ} \mathrm{C}$ hydrothermal fluids as detected by a new analytical method. J. Geophys. Res. 115, G03021.

Kawagucci, S., Chiba, H., Ishibashi, J., Yamanaka, T., Toki, T., Muramatsu, Y., Ueno, Y., Makabe, A., Inoue, K., Yoshida, N., Nakagawa, S., Nunoura, T., Takai, K., Takahata, N., Sano, Y., Narita, T., Teranishi, G., Obata, H. and Gamo, T. (2011) Hydrothermal fluid geochemistry at the Iheya North field in the mid-Okinawa Trough: Implication for origin of methane in subseafloor fluid circulation systems. Geochem. $J ., 45,109-124$.

Kawagucci, S., Ueno, Y., Takai, K., Toki, T., Ito, M., Inoue, K., Makabe, A., Yoshida, N., Muramatsu, Y., Takahata, N., Sano, Y., Narita, T., Teranishi, G., Obata, H., Nakagawa, S., Nunoura, T. and Gamo, T. (2013) Geochemical origin of hydrothermal fluid methane in sediment-associated fields and its relevance to the geographical distribution of whole hydrothermal circulation. Chem. Geol. 339, 213-225.

Kinoshita, M. and Yamano, M. (1997) Hydrothermal regime and constraints on reservoir depth of the Jade site in the Mid-Okinawa Trough inferred from heat flow measurements. J. Geophys. Res. 102, 3183-3194.

Kishida, K., Sohirn, Y., Okamura, K. and Ishibashi, J. (2004) Tungsten enriched in submarine hydrothermal fluids. Earth Planet. Sci. Lett. 222, 819-827.

Kita, I., Matsuo, S. and Wakita, H. (1982), $\mathrm{H}_{2}$ generation by reaction between $\mathrm{H}_{2} \mathrm{O}$ and crushed rock: an experimental study on $\mathrm{H}_{2}$ degassing from the active fault zone, $J$. Geophys. Res., 87, 10789-10795.

Konno, U., Tsunogai, U., Nakagawa, F., Nakaseama, M., Ishibashi, J., Nunoura, T. and Nakamura, K. (2006) Liquid $\mathrm{CO}_{2}$ venting on the seafloor: Yonaguni knoll VI hydrothermal system, Okinawa Trough. Geophys. Res. Lett. 33, L16607.

Kusakabe, M., Komoda, Y., Takano, B. and Abiko, T. (2000) Sulfur isotopic effects in the disproportionation reaction of sulfur dioxide in hydrothermal fluids: implications for the $\delta^{34} \mathrm{~S}$ variations of dissolved bisulfate and elemental sulfur from active crater lakes. J. Volcanol. Geotherml. Res. 97, 287-307.

Lin, L. H., Slater, G. F., Lollar, B. S., Lacrampe-Couloume, G. and Onstott, T. C. (2005) The yield and isotopic composition of radiolytic $\mathrm{H}_{2}$, a potential energy source for the deep subsurface biosphere. Geochim. Cosmochim. Acta 69, 893- 
903.

Lüders, V., Pracejus, B. and Halbach, P. (2001) Fluid inclusion and sulfur isotope studies in probable modern analogue Kuroko-type ores from the JADE hydrothermal field (Central Okinawa Trough, Japan). Chem. Geol. 173, 45-58.

Marumo, K. and Hattori, K. H. (1999) Seafloor hydrothermal clay alteration at Jade in back-arc Okinawa Trough: mineralogy, geochemistry and isotope characteristics. Geochim. Cosmochim. Acta 63, 2785-2804.

Nakagawa, S., Takai, K., Inagaki, F., Chiba, H., Ishibashi, J.-I., Kataoka, S., Hirayama, H., Nunoura, T., Horikoshi, K. and Sako, Y. (2005) Variability in microbial community and venting chemistry in a sediment-hosted backarc hydrothermal system: Impacts of subseafloor phase-separation. FEMS Microbiol. Ecol. 54, 141-155.

Nakaguchi, Y., Takei, M., Hattori, H., Arii, Y. and Yamaguchi, Y. (2004) Dissolved selenium species in the Sulu Sea, the South China Sea and the Celebes Sea. Geochem. J. 38, 571580 .

Nakamura, K., Kato, Y., Kimura, M., Ando, M. and Kyo, M. (1989) Occurrence and distribution of the hydrothermal ore deposits at the Izena Hole in the Okinawa Troughsummary of the knowledge in 1988-. JAMSTEC Deepsea Research 5, 183-189 (in Japanese with English abstract).

Popp, B. N., Sansone, F. J., Rust, T. M. and Merritt, D. A. (1995) Determination of concentration and carbon isotopic composition of dissolved methane in sediments and nearshore waters. Anal. Chem. 67, 405-411.

Proskurowski, G., Lilley, M. D. and Olson, E. J. (2008) Stable isotopic evidence in support of active microbial methane cycling in low-temperature diffuse flow vents at $9^{\circ} 50^{\prime} \mathrm{N}$ East Pacific Rise. Geochim. Cosmochim. Acta 72, 20052023.

Reeves, E. P., Seewald, J. S., Saccocia, P., Bach, W., Craddock, P. R., Shanks, W. C., Sylva, S. P., Walsh, E., Pichler, T. and Rosner, M. (2011) Geochemistry of hydrothermal fluids from the PACMANUS, Northeast Pual and Vienna Woods hydrothermal fields, Manus Basin, Papua New Guinea. Geochim. Cosmochim. Acta 75, 1088-1123.

Saegusa, S., Tsunogai, U., Nakagawa, F. and Kaneko, S. (2006) Development of a multi-bottle gas-tight fluid sampler WHATS II for Japanese submersibles/ROVs. Geofluids $\mathbf{6}$, 234-240.

Sakai, H., Gamo, T., Ishibashi, J., Shitashima, K., Kim, E.-S., Yanagisawa, F., Tsutsumi, M., Sano, Y., Wakita, H., Tanaka, T., Matsumoto, T., Naganuma, T. and Mitsuzawa, K. (1990a) Unique chemistry of the backarc basin hydrothermal solutions at the mid-Okinawa Trough. Geophys. Res. Lett. 17, 2133-2136.

Sakai, H., Gamo, T., Kim, E.-S., Tsutsumi, M., Tanaka, T., Ishibashi, J., Wakita, H., Yamano, M. and Oomori, T. (1990b) Venting of caron dioxide-rich fluid and hydrate formation in mid-Okinawa Trough Backarc Basin. Science 248, 1093-1096.
Sano, Y., Tokutake, T. and Takahata, N. (2008) Accurate measurement of atmospheric helium isotopes. Anal. Sci. 24, 521525.

Seewald, J. S. (2003) Organic-inorganic interactions in petroleum-producing sedimentary basins. Nature 426, 327333.

Seewald, J. S., Seyfried, W. E., Jr. and Shanks, W. C., III (1994) Variations in the chemical and stable isotope composition of carbon and sulfur species during organic-rich sediment alteration: An experimental and theoretical study of hydrothermal activity at Guaymas basin, Gulf of California. Geochim. Cosmochim. Acta 58, 5065-5082.

Seyfried, W. E., Jr. (1987) Experimental and theoretical constraints on hydrothermal alteration processes at midocean ridges. Ann. Rev. Earth Planet. Sci. 15, 317-335.

Shinjo, R., Chung, S.-L., Kato, Y. and Kimura, M. (1999) Geochemical and $\mathrm{Sr}-\mathrm{Nd}$ isotopic characteristics of volcanic rocks from the Okinawa Trough and Ryukyu Arc: Implications for the evolution of a young, intracontinental back arc basin. J. Geophys. Res. 104, 10591-10608.

Suzuki, R., Ishibashi, J.-I., Nakaseama, M., Konno, U., Tsunogai, U., Gena, K. and Chiba, H. (2008) Diverse range of mineralization induced by phase separation of hydrothermal fluid: a case study of the Yonaguni IV hydrothermal field in the Okinawa Trough Backarc Basin. Resour. Geol. 58, 267-288.

Tivey, M. K. (2007) Generation of seafloor hydrothermal vent fluids and assciated mineral deposits. Oceanography 20, 5065.

Umezawa, T., Aoki, S., Nakazawa, T. and Morimoto, S. (2009) A high-precision measurement system for carbon and hydrogen isotopic ratios of atmospheric methane and its application to air samples collected in the western Pacific region. J. Meteor. Soc. Jpn. 87, 365-379.

Von Damm, K. L. (1995) Controls on the chemistry and temporal variability of seafloor hydrothermal fluids. Seafloor Hydrothermal Systems: Physical, Chemical, Biological, and Geological Interactions (Humphris, S., Fornari, D. and Zierenberg, R., eds.), 222-247, American Geophysical Union, Washington, D.C.

Von Damm, K. L., Edmond, J. M., Grant, B. and Measuers, C. I. (1985) Chemistry of submarine hydrothermal solutions at $21^{\circ} \mathrm{N}$, East Pacific Rise. Geochim. Cosmochim. Acta 49, 2197-2220.

Von Damm, K. L., Bischoff, J. L. and Rosenbauer, R. J. (1991) Quartz solubility in hydrothermal seawater-an experimental-study and equation describing quartz solubility for up to $0.5-\mathrm{M} \mathrm{NaCl}$ solutions. Am. J. Sci. 291, 9771007.

Yamanaka, T., Mizota, C., Matsuyama-Serisawa, K., Kakegawa, T., Miyazaki, J., Mampuku, M., Tsutsumi, H. and Fujiwara, Y. (2008) Stable isotopic characterization of carbon, nitrogen and sulfur uptake of Acharax japonica from central Japan. Plankton Benthos Res. 3, 36-41. 